\title{
Myocardial damage and valve replacements
}

\author{
H. M. SINGH and E. H. HORTON \\ Sully Hospital, nr. Cardiff
}

\begin{abstract}
Forty patients who came to necropsy over a period of five years due to myocardial damage sustained during cardiac valve replacements were studied. The clinical presentation of myocardial damage was assessed in relation to the preoperative cardiac status. The cause and nature of myocardial damage were assessed at necropsy. Evidence of clinical, electrocardiographic and aortographic coronary atheroma was correlated with distribution at necropsy, and the value of selective coronary angiography in perfusing the coronary arteries during cardiopulmonary bypass is stressed. The causes of myocardial damage could be classified as (a) thrombo-embolic, $(b)$ iatrogenic damage to the coronary arteries, and $(c)$ poor or absent coronary perfusion during cardiopulmonary bypass. A case is made for the importance of coronary perfusion during cardiopulmonary bypass.
\end{abstract}

With better understanding of the nutrient requirements of the myocardium, deaths due to myocardial damage sustained during cardiopulmonary bypass are now fortunately infrequent. However, over a period of five years (1965 to 1969) 40 such patients came to necropsy at Sully Hospital, an incidence of about $5 \%$ in a yearly output of about 120 valve replacements. The aim of this paper is to study the pathophysiology of myocardial damage in these patients with reference to the incidence of coronary artery disease and to assess the factors adverse to the myocardium during and after cardiopulmonary bypass. In particular, the role of coronary perfusion is outlined, because its use is debatable, and because oxygen requirements and the coronary blood flow demands of the myocardium with non-pulsatile flow and hypothermic perfusate in the beating and fibrillating heart are only now being gradually understood (Sterns, Bonnabeau, and Lillehei, 1966 ; Vasko, 1967). When coronary atheroma predominates and results in areas of perfusion deficit in the myocardium, the role of coronary perfusion during cardiopulmonary bypass assumes all the more importance. It is in respect of this role that we have looked critically at our coronary perfusion techniques and related them to the myocardial damage sustained in this group of patients. Some of the surgical hazards to the coronary circulation which contributed to the myocardial damage in some of these patients are detailed.

\section{MATERIALS AND METHODS}

Clinical MATERIal Table I depicts the age distribution in our patients. The sex ratio was equal. Table II analyses the valve replacements carried out.
T A B L E I

AGE DISTRIBUTION

\begin{tabular}{c|c}
\hline Age (yr) & No. of Patients \\
\hline Below 30 & 2 \\
$31-40$ & 5 \\
$41-50$ & 12 \\
$51-60$ & 17 \\
61 and over & 4 \\
\hline \multicolumn{2}{c}{ Mean age 55.3 years }
\end{tabular}

T A B L E I I

VALVE REPLACEMENTS

\begin{tabular}{|c|c|c|}
\hline & & No. of Patients \\
\hline $\begin{array}{l}\text { Aortic valve } . . \\
\text { Mitral valve } \\
\text { Aortic and mitral valves } \\
\text { Aortic, mitral and tricuspid } \\
\text { valves }\end{array}$ & $\begin{array}{l}\because \\
\cdots \\
\cdots\end{array}$ & $\begin{array}{r}24 \\
11 \\
3 \\
2\end{array}$ \\
\hline
\end{tabular}

Cardiac status was appraised by right and left heart catheterization. Table III shows the cardiac index, pulmonary artery pressures, and pulmonary vascular resistance in these patients.

A history of chest pain typical of angina pectoris was present in 16 patients preoperatively. Thirteen of these had aortic valve disease and 3 mixed mitral lesions. Electrocardiographic evidence of myocardial ischaemia, as shown by the presence of ' $Q$ ' waves and ST-T changes, occurred in 4 of these patients. Table IV summarizes the findings as regards coronary artery filling in 32 aortograms performed.

PERfusion Details Perfusion technique in the 40 patients was fairly uniform. A 24-in. Kay-Cross type disc oxygenator was used in most cases, and body temperature was brought down to $30^{\circ} \mathrm{C}$. Active cooling of the body to below $25^{\circ} \mathrm{C}$. was undertaken in 
T A B L E I I I

\begin{tabular}{|c|c|}
\hline & No. of Patients \\
\hline $\begin{array}{c}\text { Cardiac index } \\
\text { (1./min./m. }{ }^{2} \text { ) } \\
\text { Below } 1 \cdot 5 \\
1 \cdot 6-2 \cdot 0 \\
2 \cdot 1-2 \cdot 5 \\
2 \cdot 6-3 \cdot 0 \\
\text { Above 3.0 }\end{array}$ & $\begin{array}{l}1 \\
6 \\
6 \\
3 \\
3 \\
7\end{array}$ \\
\hline Total & 23 \\
\hline $\begin{array}{c}\text { Pulmonary artery } \\
\text { pressure }(\mathrm{mm} . \mathrm{Hg}) \\
\text { Below } 40 \\
40-60 \\
\text { Over } 60\end{array}$ & $\begin{array}{r}14 \\
4 \\
8\end{array}$ \\
\hline Total & 26 \\
\hline $\begin{array}{l}\text { Pulmonary vascular } \\
\text { resistance (units) } \\
\text { Below } 4 \\
4-12 \\
\text { Over } 12\end{array}$ & $\begin{array}{r}14 \\
8 \\
1\end{array}$ \\
\hline Total & 23 \\
\hline
\end{tabular}

T A B L E I V

AORTOGRAPHIC FINDINGS

\begin{tabular}{|c|c|c|}
\hline & & No. of Patients \\
\hline $\begin{array}{l}\text { Good coronary filling of both vessels } \\
\text { Poor coronary filling of one vessel: } \\
\text { Left coronary .. } \\
\text { Anterior descending branch } \quad . \\
\text { Circumflex branch } \\
\text { Right coronary } \ldots \\
\text { Poor coronary filling of both vessels }\end{array}$ & $\begin{array}{l}\cdots \\
\cdots \\
\cdots \\
\cdots \\
\cdots \\
\cdots\end{array}$ & $\begin{array}{l}3 \\
3 \\
2 \\
1\end{array}$ \\
\hline
\end{tabular}

five patients when the perfusion flows fell too far below the predicted values. Haemodilution with PCV of about $30 \%$ was usual. Blood gases and serum potassium were monitored every half an hour. In the single patient who developed a base deficit of -10 , the low perfusion pressure resulted from proximal obstruction in the left femoral artery, the site of arterial return. In only one patient did the serum potassium level drop below $3.0 \mathrm{mEq} /$ litre for any two readings. Table $\mathrm{V}$ shows the total aortic crossclamp time in the 40 patients studied.

T A B L E V

TOTAL AORTIC CROSS-CLAMP TIME

\begin{tabular}{c|c}
\hline Minutes & No. of Patients \\
\hline Nil & 7 \\
$20-60$ & 5 \\
$60-90$ & 2 \\
$90-120$ & 6 \\
$120-180$ & 14 \\
Over 180 & 6 \\
\hline
\end{tabular}

The coronary arteries were cannulated in 29 patients. Coronary perfusion was by two separate Watson-Marlow flow inducers (type MHRE). Arterial blood was taken direct from the oxygenator via a heat-exchanger. By prior pump calibration the flow to each coronary artery was known. It was usualo for the myocardium to be cooled to $28^{\circ} \mathrm{C}$. In 16 을 patients, however, myocardial hypothermia of around $\frac{\bar{s}}{5}$ $15^{\circ} \mathrm{C}$. had to be undertaken when coronary arteries $\Phi$ could not be satisfactorily perfused and hypoxico myocardial damage seemed to be imminent. Coronaryes flows and line pressures are shown in Table VI.

T A B LE V I

\begin{tabular}{|c|c|c|c|}
\hline \multicolumn{2}{|c|}{$\begin{array}{l}\text { Total Coronary Flow } \\
(\mathrm{ml} . / \mathrm{min} .)\end{array}$} & $\begin{array}{l}\text { No. of } \\
\text { Patients }\end{array}$ & $\begin{array}{c}\text { No. of Patients with } \\
\text { Line Pressure above } \\
120 \mathrm{~mm} . \mathrm{Hg}\end{array}$ \\
\hline $\begin{array}{l}\text { Below } 200 \\
200-400 \\
\text { Over } 400\end{array}$ & $\begin{array}{l}\cdots \\
\cdots \\
\cdots\end{array}$ & $\begin{array}{r}10 \\
11 \\
8\end{array}$ & $\begin{array}{l}\mathrm{Nil} \\
4 \\
4\end{array}$ \\
\hline
\end{tabular}

Coronary perfusion was deemed satisfactory on the basis of the following stringent criteria:

(a) that both coronaries were perfused and thateo the period of total myocardial ischaemia was re- -7 stricted to less than 20 minutes during a particular cardiopulmonary bypass procedure;

(b) that total flow through both coronaries, commensurate with the size of the myocardium, waso above $300 \mathrm{ml}$. per minute; and

(c) that to allow this flow through the coronary bed the line pressures were below $120 \mathrm{~mm}$. of mercury.

Based upon the above criteria, three distinct groups of patients emerged, as shown in Table VII.

T A B L E V I I

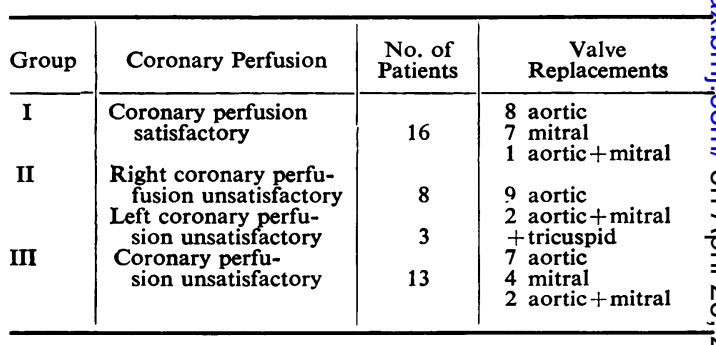

Clinico-PATHOLOGICAL ASPECTS Clinical presentation of myocardial damage was studied in all cases. Biochemical, electrocardiographic, and radiological data were analysed. An attempt was made to correlate the preoperative cardiac status with the particular mode of presentation. At necropsy, distribution of coronary atheroma in relation to preoperative assess? ment of coronary artery disease was studied. Causes of myocardial damage were delineated and an attemp was made to correlate a particular type of myocardia damage with a particular causative factor. 
RESULTS

As shown in Table VIII, more than half the deaths occurred on the day of the cardiopulmonary bypass.

\section{T A B L E V I I I}

\begin{tabular}{|c|c|c|}
\hline Time of Death & & No. of Patients \\
\hline $\begin{array}{l}1 \text { (a) At the end of perfusion } \\
\text { (b) } 2 \text { hours later when the } \\
\text { being closed } \\
\text { (c) Within the first } 24 \text { hours } \\
2 \text { Within } 24-72 \text { hours } \\
4 \text { During the first week } \\
4 \text { During the second week }\end{array}$ & $\begin{array}{cc}\text { chest } & \ldots \\
\ldots & \ldots \\
\ldots & \ldots \\
\ldots & \cdots \\
\ldots & \cdots \\
\ldots & \cdots\end{array}$ & $\begin{array}{r}10 \\
7 \\
7 \\
7 \\
6 \\
3\end{array}$ \\
\hline
\end{tabular}

In the 16 patients who survived longer than 24 hours, evidence of low cardiac output, despite intermittent positive pressure respiration and isoprenaline, was obtained. Seven of these patients showed electrocardiographic evidence of fresh posterior myocardial infarction within 24 to 48 hours of the cardiopulmonary bypass procedure. Four were subsequently found to have a stitch around the circumflex branch of the left coronary artery while the remaining three had sustained dissections of the right coronary artery. Three of the 16 patients also showed changes suggestive of pulmonary oedema on serial daily chest radiographs. In almost all patients the final episode was a ventricular fibrillation which could not be reverted. In 5 patients, however, fulminating infections contributed to death. In addition, 2 patients had gross hepatic necrosis as well.

NECROPSY FINDINGS At necropsy 17 patients had moderate to severe coronary atheroma (Table IX).

\section{T A B L E IX}

\begin{tabular}{|c|c|}
\hline $\begin{array}{c}\text { Distribution of Coronary } \\
\text { Atheroma }\end{array}$ & No. of Patients \\
\hline $\begin{array}{l}\text { Triple vessel disease } \\
\text { Double vessel disease: } \\
\text { a. Right coronary and anterior descend } \\
\text { ing branch of left } \\
\text { b. Circumflex and anterior descending } \\
\text { branches of left coronary artery } \\
\text { Single vessel disease: } \\
\text { a. Right coronary artery } \\
\text { b. Anterior descending branch of left } \\
\text { coronary artery } \\
\text { c. Circumflex branch of left coronary } \\
\text { artery } \\
\text {... }\end{array}$ & $\begin{array}{l}2 \\
1 \\
4 \\
4 \\
1\end{array}$ \\
\hline
\end{tabular}

Table $\mathbf{X}$ describes the nature of myocardial damage.

The causes of myocardial damage were defined and were found to be almost equally divided between (1) thrombo-embolic episodes, (2) iatro- genic damage to the coronary circulation, and (3) poor or absent coronary perfusion during cardiopulmonary bypass.

T A B LE $X$

\begin{tabular}{|c|c|}
\hline Nature of Myocardial Damage & No. of Patients \\
\hline 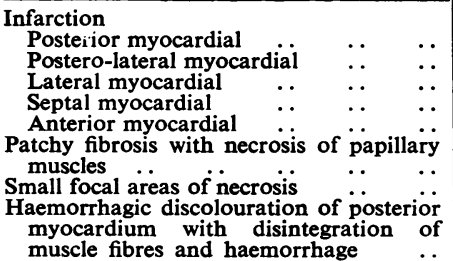 & $\begin{array}{rr}13 & \\
4 & \\
1 & \\
1 & \\
2 & 21 \\
& 11 \\
& 5\end{array}$ \\
\hline
\end{tabular}

\section{T A B L E X I}

\begin{tabular}{|c|c|c|}
\hline Group & $\begin{array}{l}\text { No. of } \\
\text { Patients }\end{array}$ & $\begin{array}{l}\text { No. of Patients with Causes } \\
\text { of Myocardial Damage }\end{array}$ \\
\hline $\begin{array}{l}\text { Group I: } \\
\text { satisfactory } \\
\text { coronary } \\
\text { perfusion }\end{array}$ & 16 & $\begin{array}{l}7 \text { Thrombo-embolic causes } \\
7 \text { Iatrogenic damage to coronary } \\
\text { vessels } \\
3 \text { Patients had severe triple }\end{array}$ \\
\hline $\begin{array}{l}\text { Group II: } \\
\text { coronary } \\
\text { perfusion of } \\
\text { one artery } \\
\text { deficient } \\
\text { Group III: } \\
\text { unsatisfactory } \\
\text { coronary } \\
\text { perfusion }\end{array}$ & 13 & $\begin{array}{l}6 \text { Thrombo-embolic causes } \\
5 \text { Iatrogenic damage to coronary } \\
\text { vessels } \\
4 \text { Patients had severe right or } \\
\text { left coronary artery disease } \\
3 \text { Iatrogenic damage to coronary } \\
\text { vessels } \\
2 \text { Patients had severe triple } \\
\text { vessel disease }\end{array}$ \\
\hline
\end{tabular}

Table XI summarizes the causes of myocardial damage in the three groups of patients, divided on the basis of adequacy of coronary perfusion during cardiopulmonary bypass.

Thus most patients in group III sustained myocardial damage because of unsatisfactory coronary perfusion.

\section{DISCUSSION}

Our original method of coronary perfusion on bypass was by taking a coronary supply line off the systemic arterial line via a Y-piece, flow to the heart being controlled by a gate-clip. Calibration of the apparatus before clinical use was by adjusting the gate-clip to allow delivery of 200 $300 \mathrm{ml} . /$ minute at the calculated systemic flow with a systemic line pressure of $250 \mathrm{mmHg}$. However, variations in systemic flow or line pressures resulted in alterations in coronary flow of uncertain degree. It is almost certain that some of our patients succumbed from irreversible myocardial damage from 'over-perfusion' of the myocardium. With our present method of coronary perfusion, using two separate coronary artery 
pumps, delivering blood from the oxygenator to each coronary artery separately via a heatexchanger, over-perfusion is eliminated. There is little difference in the pressures in the coronary line and coronary artery (Shaw, Mosher, Ross, Joseph, and Lee, 1962), and mean pressures of 80 to $100 \mathrm{mmHg}$ in the coronary line are relied upon to provide 'physiological' coronary flows. For the time usually involved in aortic valve replacement the temperature is reduced to $28^{\circ} \mathrm{C}$.

However, the problem of myocardial perfusion in the presence of coronary atheroma remains. In our series one-third of the patients had coronary atheroma severe enough to jeopardize coronary perfusion. Furthermore, preoperative evidence of coronary artery disease based on clinical symptoms, electrocardiograms, and aortograms was largely negative and correlated poorly with the post-mortem findings. This agrees with the work of Sones and Shirey (1962), and we rely increasingly on selective coronary angiograms not only to delineate more fully the pathological processes in patients undergoing valve replacements, but also to anticipate the problem of myocardial perfusion during cardiopulmonary bypass.

Most of the group III patients and three of the group II patients in whom the cardiopulmonary bypass was unduly prolonged died as a result of absent or poor coronary perfusion, thus contributing to mortality in almost one-third of the patients. The causes of inability to perfuse the coronary arteries in this group ranged from the narrowness of the coronary ostia or their damage at subsequent cannulation to the involvement of the coronary arteries with atheroma. When coronary atheroma was present to any degree of severity, the coronary cannulae flicked out of the coronary arteries with even the most modest of coronary flows; so frequently as to be pathognomonic of atheromatous coronary arteries. In this situation, despite further cooling of the myocardium to about $15^{\circ} \mathrm{C}$. and coronary perfusion with minimal flow rates to keep the coronary line pressure from rising, the outcome was fatal if the cardiopulmonary bypass was at all prolonged. Neither was the situation helped in eight patients by perfusing the coronary bed at higher line pressures than $120 \mathrm{~mm}$. with 'stitched in' coronary cannulae to ensure better coronary flows. In fact, with Vasko (1967) and Brown, Braimbridge, Miles, Gerbode, and Aguilar (1969), we believe this might have contributed to 'over-perfusion' of the coronary bed, culminating in a fatal outcome in at least three of the patients. At these line pressures we have not observed myocardial capillary rupture and haemorrhage (Hirose and Madden, 1964) 단 necropsy as a direct result of coronary perfusiow; although in three unrelated patients in whom coronary perfusion was at physiological pressures disintegration of myocardial muscle fibres with haemorrhage was in fact the only necrops finding.

The surgical hazards to the circumflex brane of the left coronary artery as it courses from origin to form the anatomical relation of the mitral ring are now well recognized. In the six patients in our series the occlusive damage to the vessel by a surgical stitch occurred at a distange of 6 to $10 \mathrm{~mm}$. from its origin, particularly when the anterior cusp was grossly calcified and calcium had to be cleared from its bed in the mitrơ ring. Damage to the coronary ostia, leading endothelial blockage of the ostia, or dissection the coronary artery occurred in nine patients the earlier series but is now infrequent due to the use of softer tipped coronary cannulae (Ramsejy de la Torre, Linhart, and Wheat, 1967). Agai early cannulation of the coronary arteries now undertaken during replacement for calcific aor valve disease has reduced the incidence off coronary calcific embolism (Glotzer, Shaw, and Scannell, 1962). The risks to the myocardium from air and particulate embolism, particular when there is gross enlargement of cardiac chambers, still remain and can only be prevented by meticulous care.

More than half of our patients died following cessation of cardiopulmonary bypass or soon after. In the 16 who survived longer than 34 hours, the haemodynamic situation gradua By deteriorated despite intermittent positive pressume respiration, isoprenaline and cardiotonic drugs. \$n all there was only a marginal correlation between the length of survival after cardiopulmonary bypas and the preoperative cardiac status. Neither of the degree of gross myocardial damage influenee the length of survival in these patients. Thus, tin the cases where coronary perfusion was inadequate, death usually occurred at the end \&f cardiopulmonary bypass, and gross damage to the myocardium was minimal. Again, the ty of myocardial damage did not correlate with afey particular causative factor in our series. Our own view is that if particular care is taken to keep tbe coronary line pressure between 80 and $100 \mathrm{~m}$ 角. $\mathrm{Hg}$ with a moderate hypothermic myocardial pertfusion, the heart being kept gently beating, or $\frac{\text { at }}{\mathrm{a}}$ worst allowed to fibrillate, myocardial damate 
due to coronary perfusion itself in the absence of coronary atheroma does not occur.

It is conceded that there is evidence to suggest that the healthy human myocardium subjected to complete ischaemia for 45 minutes at body temperature will recover sufficiently to support circulation, and that cooling to $30^{\circ} \mathrm{C}$. will prolong this period (Kay, Nogueira, Suzuki, Postigo, and Mendelsohn, 1961 ; Glotzer et al., 1962). In a heart damaged by previous cluronic ischaemia, rheumatic fever and coronary atheroma with hypertrophy and dilatation of its chambers, the problem is different. As it is difficult to quantitate this damage to the myocardium against the ischaemic period which might be tolerated in an individual patient, our view is that ischaemia of the heart for anything but the shortest period of time is less safe than good coronary perfusion.

We should like to thank Dr. R. M. E. Seal for examining the pathological material in all cases and for making this study possible.

\section{REFERENCES}

Brown, A. Hedley, Braimbridge, M. V., Miles, N. R., Gerbode, F., and Aguilar, M. J. (1969). The effect of excessively high perfusion pressures on the histology, histochemistry, birefringence, and function of the myocardium. J. thorac. cardiovasc. Surg., 58, 655.

Glotzer, D. J., Shaw, R. S., and Scannell, J. G. (1962). Calcific coronary emboli following open valvuloplasty for aortic stenosis. Amer. J. thorac. cardiovasc. Surg., 43, 434.

Hirose, T., and Madden, R. E. (1964). Optimal coronary flow in the bypassed normothermic and hypothermic heart. J. thorac. cardiovasc. Surg., 48, 82.

Kay, E. B., Nogueira, C., Suzuki, A., Postigo, J., and Mendelsohn, D. (1961). Myocardial protection during aortic valvular surgery. Ann. Surg., 154, Suppl. p. 159.

Ramsey, H. W., de la Torre, A., Linhart, J. W., and Wheat, M. W. (1967). Complications of coronary artery perfusion. J. thorac. cardiovasc. Surg., 54, 714.

Shaw, R. F., Mosher, P., Ross, J., Jr., Joseph, J. I., and Lee, A. S. J. (1962). Physiologic principles of coronary perfusion. J. thorac. cardiovasc. Surg., 44, 608.

Sones, F. M., and Shirey, E. K. (1962). Cine coronary arteriography. Mod. Conc. cardiovasc. Dis., 31, 735 .

Sterns, L. P., Bonnabeau, R. C., and Lillehei, C. W. (1966). Coronary resistance changes with hypothermic perfusion. J. thorac. cardiovasc. Surg., 51, 579.

Vasko, J. S. (1967). Preservation of myocardial function during open heart surgery. Amer. J. Surg., 113, 589. 